\title{
Henckelia longisepala (Gesneriaceae), a new record for Vietnam
}

\author{
Bui H.Q. ${ }^{1,2}$, Nuraliev M.S..$^{3,4,}$, Möller M. ${ }^{5}$, Kuznetsov A.N. ${ }^{3}$, \\ Kuznetsova S.P. ${ }^{3}$, Middleton D.J. ${ }^{6} \&$ F. Wen ${ }^{7,8}$ \\ ${ }^{1}$ Institute of Ecology and Biological Resources, Vietnam Academy of Science and Technology, \\ 18 Hoang Quoc Viet Road, Cau Giay, Hanoi, Vietnam. \\ ${ }^{2}$ Graduate University of Science and Technology, Vietnam Academy of Science and Technology, \\ 18 Hoang Quoc Viet Road, Cau Giay, Hanoi, Vietnam. \\ 3Joint Russian-Vietnamese Tropical Scientific and Technological Center, Cau Giay, Hanoi, Vietnam. \\ ${ }^{4}$ Department of Higher Plants, Biological Faculty, M.V. Lomonosov Moscow State University, 1,12 Leninskie Gory, \\ Moscow - 119 234, Russia. \\ ${ }^{5}$ Royal Botanic Garden Edinburgh, 20A Inverleith Row, Edinburgh EH3 5LR, Scotland, UK. \\ ${ }^{6}$ Herbarium, Singapore Botanic Gardens, National Parks Board, 1 Cluny Road,259569 Singapore. \\ ${ }^{7}$ Guangxi Key Laboratory of Plant Conservation and Restoration Ecology in Karst Terrain, Guangxi Institute of Botany, \\ Guangxi Zhuangzu Autonomous Region, Guangxi Zhuangzu Autonomous Region, \\ Chinese Academy of Sciences, Guilin - 541 006, China. \\ ${ }^{8}$ Gesneriad Conservation Center of China (GCCC), Guilin Botanical Garden, \\ Chinese Academy of Sciences, Guilin - 541 006, China. \\ "E-mail: max.nuraliev@gmail.com
}

\begin{abstract}
Henckelia longisepala (H.W.Li) D.J.Middleton \& Mich.Möller is reported from Lai Chau and Nghe An provinces of Vietnam as a new national record of the species. An amended morphological description and photographic illustrations are provided. The distribution of $H$. longisepala is discussed with an emphasis on the floristic regions inhabited by this species. A specimen at KUN is selected for a second-step lectotypification. Two floral morphologies were found in $H$. longisepala that differ in the length of the pistil and its significance is discussed here.
\end{abstract}

Keywords: Floral phenology, Floristic regions, Hemiboeopsis.

\section{Introduction}

The genus Henckelia Spreng. (Gesneriaceae) has recently been re-circumscribed based on molecular and morphological evidence (Weber et al., 2011; Middleton et al., 2013; Möller et al., 2016). With the current delimitation, Henckelia consists of at least 70 species, mainly distributed across South, East and Southeast Asia, including the Himalayan region (Weber et al., 2011; Middleton et al., 2013; Möller et al., 2017; Krishna \& Lakshminarasimhan, 2018;

Received: 11.12.2019; Revised \& Accepted: 21.03.2020

Published Online: 11.05.2020
Borah et al., 2019; Cai et al., 2019; Sirimongkol et al., 2019; Yang et al., 2019; Janeesha \& Nampy, this issue; Kanthraj et al., this issue). In Vietnam, six species of Henckelia have been recorded, namely, $H$. anachoreta (Hance) D.J.Middleton \& Mich.Möller, H. ceratoscyphus (B.L.Burtt) D.J.Middleton \& Mich.Möller, H. fruticola (H.W.Li) D.J.Middleton \& Mich.Möller, H. grandifolia A.Dietr., H. pumila (D.Don) A.Dietr. and H. speciosa (Kurz) D.J.Middleton \& Mich.Möller (Wang et al., 1998; Ho, 2000; Phuong, 2005, 2017; Weber et al., 2011), all of which were formerly treated in the genus Chirita Buch.-Ham. ex D.Don (Wang et al., 2011; Weber et al., 2011). These species are also recorded from the southern regions of China (Wang, 1985; Wang et al., 1990, 1998; Wei et al., 2010; Weber et al., 2011). During field investigations in Lai Chau province, Northwestern Vietnam, and Nghe An province, North Central Vietnam, in 2018, we collected several specimens of Gesneriaceae, which after careful study of relevant specimens and taxonomic publications from adjacent regions (Pellegrin, 1926, 1930; Wang, 1985; Wang et al., 1990, 1998; Weber et al., 2011; Middleton et al., 2013; Möller et al., 2016; $\mathrm{Xu}$ et al., 2017) were identified as Henckelia longisepala (H.W.Li) D.J.Middleton \& Mich.Möller. 
Prior to the re-circumscription of Henckelia (Weber et al., 2011), this species was placed in the monotypic genus Hemiboeopsis W.T.Wang, which reflected its remarkable morphology (Wang et al., 1998). As highlighted by Wang (1984), H. longisepala was unusual at that time among Gesneriaceae in its stamen filaments being broadest at the middle and tapering towards ends (although this is now known in many other species of the family), anther connectives with a single triangular appendage, two unequal stigmas, and apparently two-loculed ovary. Henckelia longisepala is reported to occur in the Yunnan province of China and in Laos (Wang, 1984; Li, 1991; Wang et al., 1990, 1998; Weber et al., 2011), but was not included in the Checklist of Laos by Newman et al. (2007). The collections from Vietnam are a new record for the country. Here, we provide a detailed description and field photographs of our records to facilitate its easier identification in the future. We also confirm with specimen citations below that the reports of $H$. longisepala for Laos (Wang et al., 1998; Weber et al., 2011) are correct, and specify its localities within Laos. We summarize the available data on the distribution of this species, highlighting the floristic regions of Eastern Indochina, and discuss the flower structure and phenology in H. longisepala. Finally, we provide a second-step lectotypification of $H$. longisepala because there are two herbarium sheets of the type collection at the herbarium of the supposed lectotype.

Henckelia longisepala (H.W.Li) D.J.Middleton \& Mich.Möller, Taxon 60(3): 776. 2011. Hemiboeopsis longisepala (H.W.Li) W.T.Wang, Acta Bot. Yunnan. 6(4): 399. 1984. Lysionotus longisepalus H.W.Li, Bull. Bot. Res., Harbin 3(2): 1. 1983. Lectotype (first-step designated by Wang, 1984; second-step designated here): CHINA, Yunnan, Hekou, Lengshui Gou, $250 \mathrm{~m}$, 20.04.1953, K.H. Cai 464 (KUN [KUN1219162 digital image!]; isolectotypes KUN [KUN1219165 digital image!], PE [PE00030765 digital image!]).

Figs. 1-3

Subshrubs, terrestrial, 25-80(100) cm tall; underground part a short vertical rhizome. Stems simple, apically densely brownish appressed pubescent, basally glabrescent. Leaves opposite, equal to subequal in a pair; petioles $1.5-5.5 \mathrm{~cm}$ long, covered with long appressed brownish hairs when young, glabrescent; leaf blade ovate to oblanceolate, 9-24 × 3-6.5 cm, base attenuate to broadly cuneate, margins repand-crenulate to nearly entire, apex acuminate, glabrous to sparsely ciliate, especially abaxially on veins and especially when young, adaxially dark green, abaxially glaucous-green or sometimes dark purple; secondary veins $8-17$ pairs; midvein and secondary veins prominent on both surfaces. Inflorescences axillary, 3-9-flowered dense umbel-like cymes. Peduncles 1.5-2 cm long, pubescent or (in Vietnamese plants) glabrescent. Each branch of cyme subtended by a bract; 2 basal bracts opposite, adjoining, forming a globose involucre, nearly orbicular to ovate-orbicular, 1.7$2 \times 1.7-2.5 \mathrm{~cm}$, thick leathery especially along midrib, glabrous or abaxially pubescent, purplish white to dark purple; other bracts similar to basal bracts but more delicate and somewhat smaller. Pedicels 3-6 mm long, glabrous, purple. Sepals apparently free (tube lacking), equal, spathulate, 12$20 \times 2.5-3 \mathrm{~mm}$, base cuneate, margin entire, apex rounded, glabrous, white with purple tint especially towards apex to entirely purple. Corolla zygomorphic, 3.5-4.5 × c. $1.3 \mathrm{~cm}$, purple to white, inside with two elevated yellow stripes on lower (abaxial) surface; tube funnelform-tubular, not swollen, slightly bent in adaxial direction, much longer than limb, 2.5-3.5 cm long, glabrous outside and inside; limb 2-lipped, glabrous or (in Vietnamese plants) adaxially uniformly covered with dense very short hairs; adaxial lip 2-lobed, 0.5$1 \mathrm{~cm}$ long, shorter than abaxial lip; abaxial lip 3lobed, 1-1.2 cm long, lobes equal; all five lobes semicircular, with overlapping margins. Stamens 2 abaxial (lower), adnate to corolla tube abaxially behind middle, included, c. $1.5 \mathrm{~cm}$ long; filaments conspicuously swollen in middle part (fusiform), $1-1.5 \mathrm{~mm}$ broad at middle, $c .0 .4 \mathrm{~mm}$ broad at base and apex, glabrous to puberulent near apex, whitish; anthers dorsifixed, coherent by adaxial surfaces, ellipsoid, 2.8-3.2 mm long, abaxially puberulent 


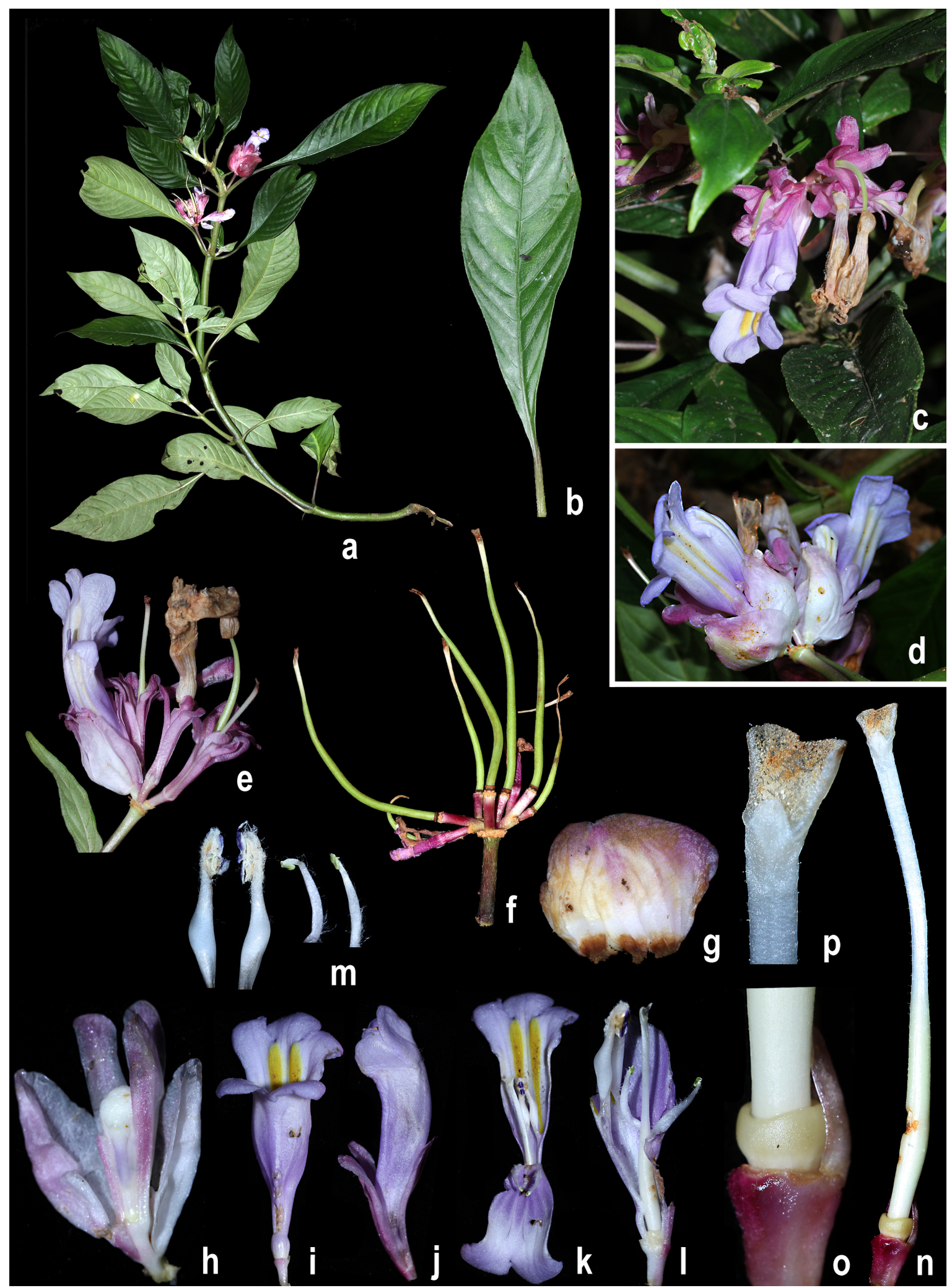

Fig. 1. Henckelia longisepala (H.W.Li) D.J.Middleton \& Mich.Möller collected from Lai Chau province: a. Habit; b. Leaf-adaxial view; c. Cymefront view; d. Cyme-view from below; e. Cyme-side view; $\mathbf{f}$. Cyme with young capsules; $\mathbf{g}$. Basal bract of cyme; $\mathbf{h}$. Flower bud and two inflorescence bracts; i. Corolla-adaxial view; j. Flower bud-side view; k. Corolla cut-open showing pistil, stamens and staminodes; I. Longitudinally dissected corolla showing androecium and pistil with disc; $\mathbf{m}$. Stamens and staminodes; $\boldsymbol{n}$. Pistil and disc; $\mathbf{0}$. Ovary base with disc; $\mathbf{p}$. Stigmas (from H.Q. Bui 215; photos by H.Q. Bui). 

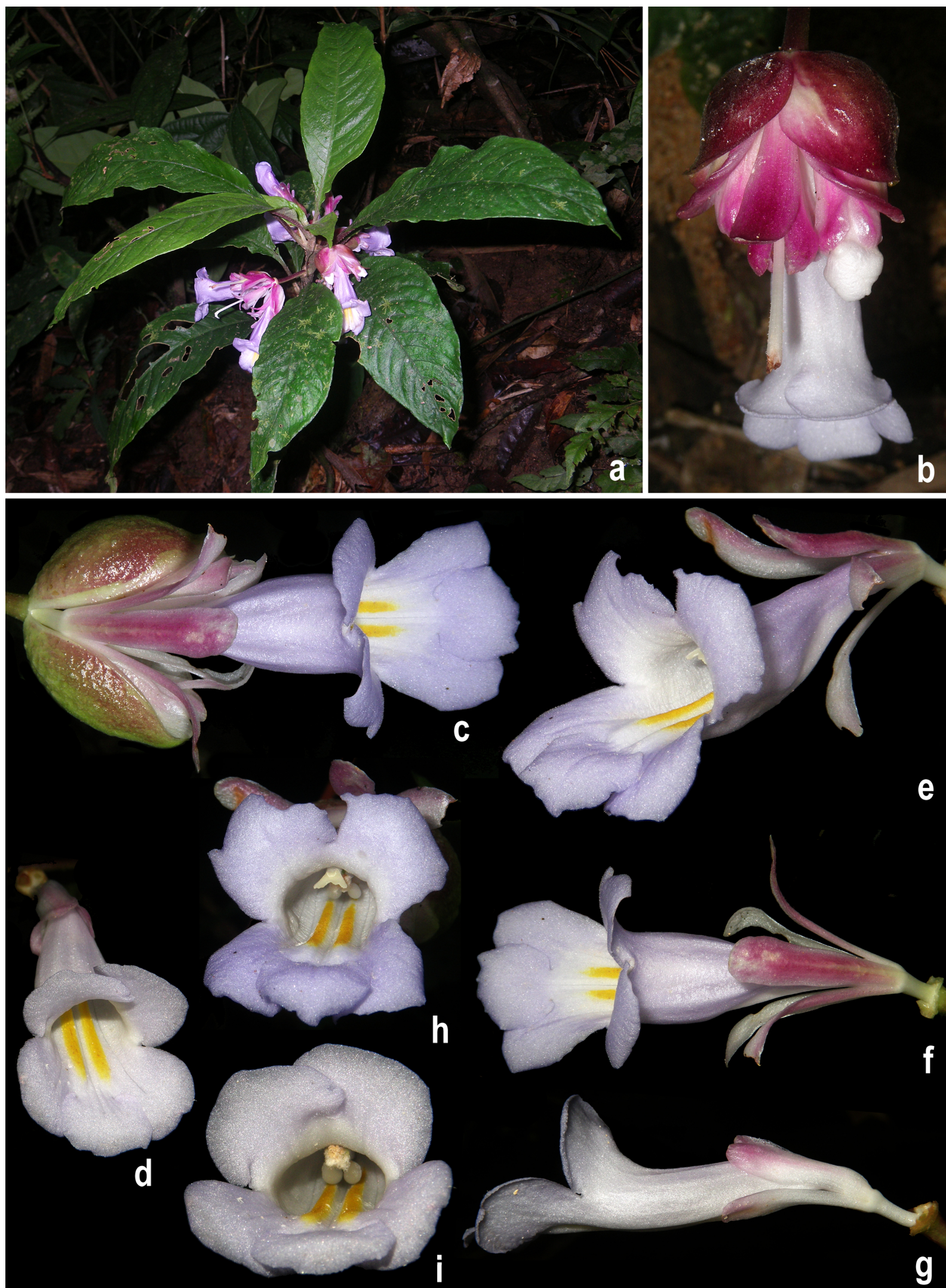

Fig. 2. Henckelia longisepala (H.W.Li) D.J.Middleton \& Mich.Möller collected from Nghe An province: a. Habit; b, c. Cyme- adaxial view; d, e. Flower-oblique view; f. Flower-adaxial view; g. Flower-side view; h. Long-styled flower-front view; i. Short-styled flower-front view (from M.S. Nuraliev, A.N. Kuznetsov \& S.P. Kuznetsova 2168; photos by M.S. Nuraliev). 


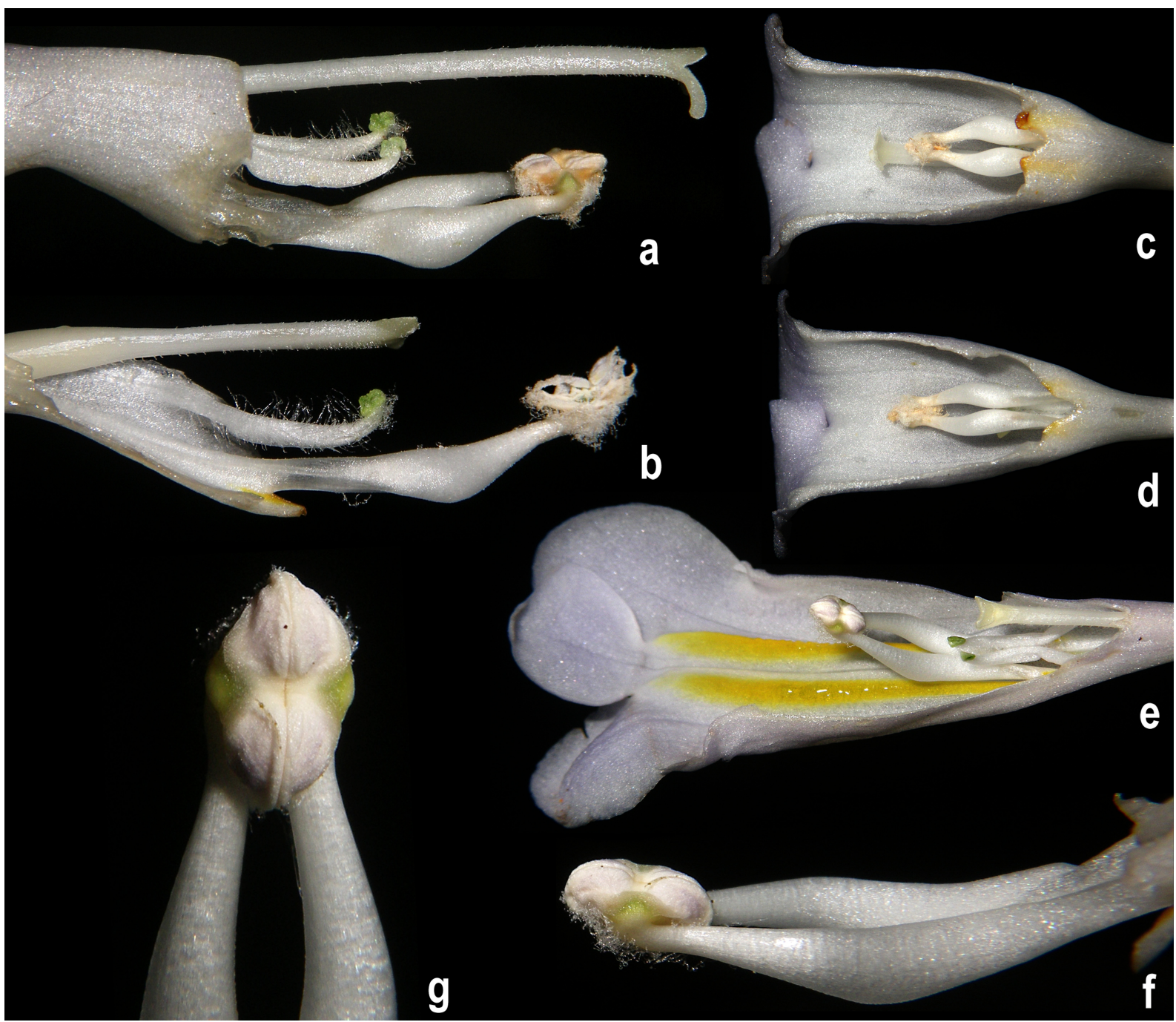

Fig. 3. Henckelia longisepala (H.W.Li) D.J.Middleton \& Mich.Möller collected from Nghe An province: a, b. Androecium and gynoecium-side view; c, d. Adaxial half of corolla, style and stamens-abaxial view; e. Abaxial half of corolla, style and stamens-oblique side view; f. Coherent stamens-side view; g. Undehisced fertile anthers-adaxial view (from M.S. Nuraliev, A.N. Kuznetsov \& S.P. Kuznetsova 2168; photos by M.S. Nuraliev).

with dense tuft of hairs, creamy white or dark purple; thecae divaricate, confluent, dehiscing longitudinally; connectives each with 1 abaxial appendage, appendage triangular, $0.5-1.8 \mathrm{~mm}$ long. Staminodes 3; 2 staminodes paired, adaxial (upper), adnate to corolla tube adaxially slightly behind fertile stamens, c. $1 \mathrm{~cm}$ long, filaments without swellings, thinner than those of fertile stamens, covered by long spreading hairs throughout their length, whitish, antherodes small, greenish; median (unpaired adaxial) staminode club-shaped, $\leq 1 \mathrm{~mm}$ long, greenish white. Disc ring-like, 1-2 $\mathrm{mm}$ long, brownish yellow. Pistil included, 2.1-2.6 cm long (but see below), white; ovary superior, linear, 2-loculed, $0.9-1.1 \mathrm{~cm}$ long, glabrous, becoming green after anthesis; placentas 2, axile; style c. $1.5 \mathrm{~cm}$ long, sparsely glandular puberulent; stigmas 2, strongly unequal: adaxial small, about $1 \mathrm{~mm}$ long, semiorbicular, abaxial large, about $2.5 \mathrm{~mm}$ long, broadly flabellate, emarginate; stigmatic surface densely minutely pubescent. Immature capsules straight in relation to pedicel, linear, much longer than calyx; valves probably 2, straight, not twisted. Mature capsules 6-10 cm long. Seeds unappendaged, fusiform, $c$. $0.25 \mathrm{~mm}$ long, dark brown. 
Flowering \& fruiting: Flowering from April to June and fruiting from May to August.

Habitat: Henckelia longisepala occurs at elevations of 100-1300 m (across its entire distribution range). In Lai Chau province, it was found on the shady sides of rocks, under the canopy of evergreen broadleaf moist forest, often near streams and in other wet habitats, together with representatives of the genera Cyathea Sm., Lindera Thunb., Elatostema J.R.Forst. \& G.Forst., Ficus L. and Carex L. In Nghe An province ( $\mathrm{Pu}$ Hoat Nature Reserve), it is extremely common, at least within a radius of $c .2$ $\mathrm{km}$, and was observed in a wide range of habitats, including areas along a river and by streams and on local mountain slopes.

The population of $H$. longisepala found in Lai Chau province of Vietnam is located within the overall region known to be inhabited by this species in China, with the distance from the Lai Chau population to the nearest Chinese population being only about $30 \mathrm{~km}$ (Fig. 4).

Populations from both Lai Chau and Yunnan lie within the borders of the Sikang-Yunnan floristic region, which belongs to the Holarctic floristic kingdom (Takhtajan, 1986; Averyanov et al., 2003a, 2003b; Fu et al., 2019). The population from the Vietnamese Nghe An province, together with the specimens from the neighbouring Laotian Xiangkhouang province (each is about $150 \mathrm{~km}$ from the former), in contrast, is found in the North Indochinese floristic region of the Paleotropical floristic kingdom. The North Indochinese populations are about $300 \mathrm{~km}$ south of the nearest Sikang-Yunnan populations. The distribution of $H$. longisepala confirms that the species occurs not only in subtropical, but also in tropical environments, although its habitat preferences across these regions are similar.

Distribution: China, Laos and Vietnam.

Specimens examined: CHINA, Yunnan province, Hekou County, Hekou Town, Basa, Huguang, N 22³7'36", E 10351'35", 341 m, 28.07.2015, C. Rao, Y.F. Li, H.R. He, G.S. Zhang Zhang GL019
(KUN [KUN1396175 digital image]); Mafengzhai village, 200 m, 08.05.1953, K.H. Cai 990 (paratypes KUN [KUN0207552, KUN0207859 digital images]); Napai Town, 24.04.1940, H.D. Zhang 1259 (IBSC [0549824 digital image]); Wangjiaokaqinggou, 260 m, 13.04.1953, K.H. Cai 308 (paratype KUN [KUN1219150 digital image]); Xin An Zhai village, 120 m, 06.04.1953, K.H. Cai 84 (paratype KUN [KUN0200861 digital image]); Huguan, 08.04.1953, K.H. Cai 146 (KUN [paratype KUN0207858 digital image]); Jiangcheng County, Qushui Town, Nuna Village, Ganmazhai, Sanguozhuang, N 22²9'54", E 102¹5'37', 1242 $\mathrm{m}, 11.05 .2012$, Jiangcheng Investigation Team 5308260204 (IMDY [IMDY0020653 digital image]); Jinping County, Mengla Town, Xinmeng Village, 15.04.1954, Zhong Su Team (Chinese-Soviet Joint Expedition to Yunnan Prov.) 1685 (PE [PE00154615 digital image]); Mengla Town, mountain behind Xinmeng Village, 15.04.1956, Chinese-Soviet Joint Expedition to Yunnan Prov. 1747 (paratype KUN [KUN0207551 digital image]); Jingping, Taoman, 800 m, 27.04.1953, Y.C. Xue [Y.B. Xu] 284 (paratypes E [E00628132], KUN [KUN0207862, KUN0207863 digital images]); Youshan Qinggou, 400 m, 16.04.1956, ChineseSoviet Joint Expedition to Yunnan Prov. 292 (paratype KUN [KUN0207553 digital image]); Lvchun County, Banpo Town, Er'pu Village, Niuboliangzi, N 22³9'27.62", E 102¹9'38.06", 1109 m, 14.08.2019, F. Wen s.n. (IBK photos). LAOS, Xiangkhouang province, entre Nadon et la Mine

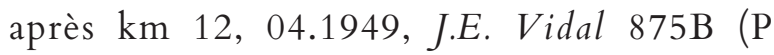
[P03851426]); Chieng Kwang [Muang Khoun], Pu Muten, 1300 m, 20.04.1932, A.F.G. Kerr 21170 (K, L [L.2824346 digital image]); VIETNAM, Lai Chau province, Muong Te district, $\mathrm{Pa} \mathrm{U}$ commune, N 22³3'41.7", E 10240'17.6", 983 m, 25.05.2018, H.Q. Bui 215 (HN, IBK, MW); Nghe An province, Que Phong district, Hanh Dich municipality, Pu Hoat Nature Reserve, 21 km NW of Kim Son town, disturbed forest, not far from river, N 19 45'34', E $104^{\circ} 48^{\prime} 05^{\prime \prime}, 850 \mathrm{~m}$, 07.05.2018, M.S. Nuraliev, A.N. Kuznetsov E S.P. 


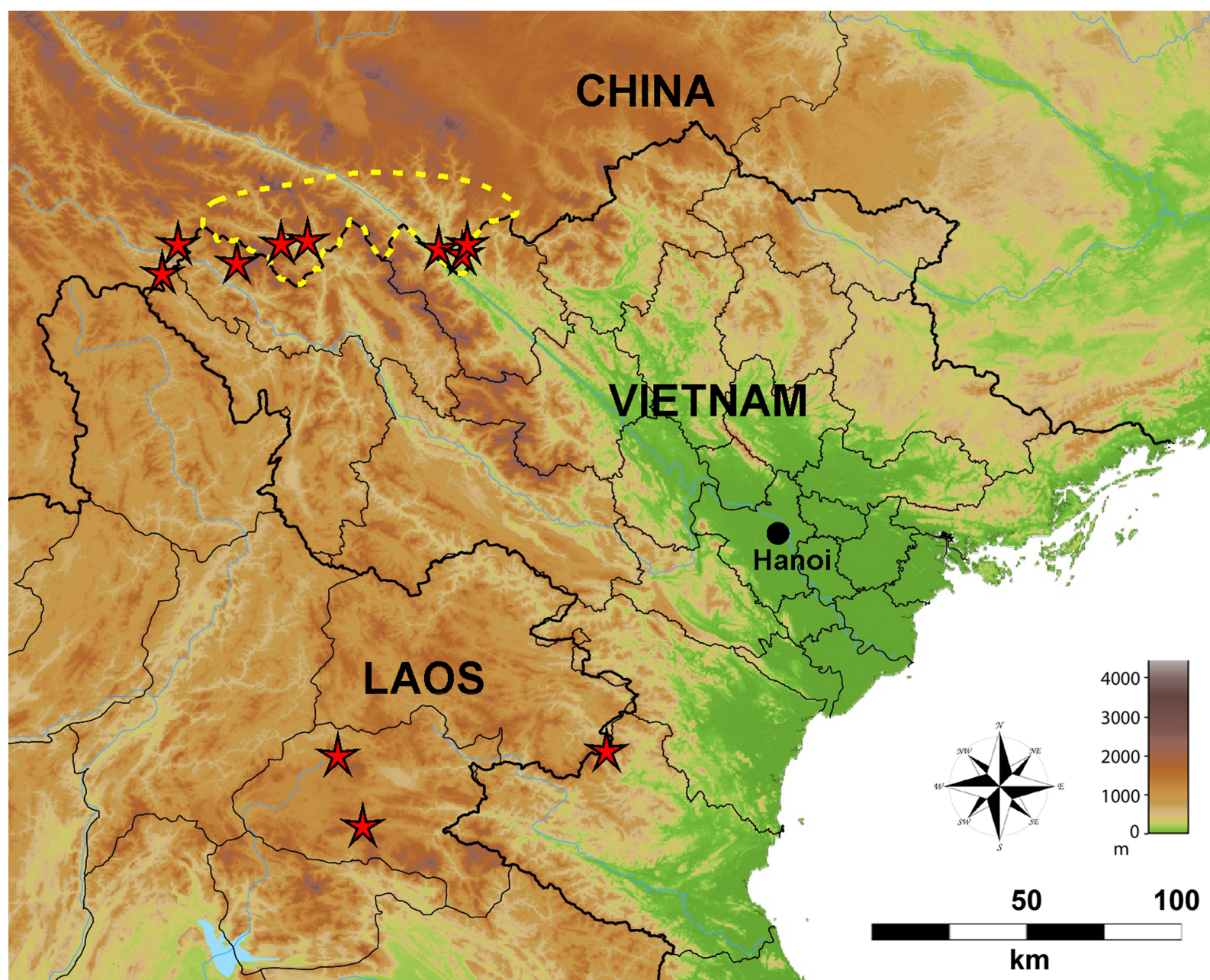

Fig. 4. Distribution map of Henckelia Iongisepala (H.W.Li) D.J.Middleton \& Mich.Möller. Red stars indicate specimens cited in this study; yellow dashed line indicates approximate area inhabited by this species in China, according to Wang et al. (1998).

Kuznetsova 2168 (IBK, MW [MW0756077], SING [SING0283527]).

Conservation status: The Extent of Occurrence (EOO) and probable Area of Occupancy (AOO) are both greater than the limits of any of the threat categories and $>10$ populations are known to exist, even if the actual AOO is actually lower than our estimate and below the threshold for Vulnerable. Consequently, $H$. longisepala is assessed here as Least Concern (LC) (IUCN Standards and Petitions Committee, 2019). In Vietnam at the $\mathrm{Pu}$ Hoat Nature Reserve the species is common and the number of mature plants is estimated to be at least several hundreds. In Yunnan, however, $H$. longisepala has been listed amongst 'Plant Species with Extremely Small Populations (PSESP)' (Yang
\& Yang, 2014), suggesting that it may require a national assessment in China in one of the threat categories.

Nomenclatural notes: The protologue of Lysionotus longisepalus (Li, 1983) contains a list of studied specimens, of which one collection ("K.H. Tsai [Cai] 464") was indicated as "Typus!". When he published the combination in Hemiboeopsis, Wang (1984) indicated a duplicate of this specimen at KUN as "holotypus" and another duplicate at PE as "isotypus", which at that time met the conditions for effective lectotypification (Art. 7.11 of ICN, Turland et al., 2018; see also McNeill, 2014). However, we have found that there are two specimens of the collection K.H. Cai 464 deposited in KUN (KUN1219162 and KUN1219165). 
Wang's choice (1984) is a first-step lectotypification (Art. 9.17) and a second step is desirable. We have selected the specimen at KUN with barcode KUN1219162 as the lectotype in a second step because it is in better condition and better shows the salient characters of the species. The specimens at PE (PE00030765) and KUN (KUN1219165) are isolectotypes.

Notes on inflorescence bracts: Henckelia longisepala was previously described as having only two basal bracts in the cymes (Li, 1983; Wang, 1984; Wang et al., 1998). This is consistent with the descriptions provided for other species of this genus, irrespective of the number of flowers in a cyme (e.g., Borah et al., 2019; Cai et al., 2019; Sirimongkol et al., 2019; Yang et al., 2019). According to Möller et al. (2018), it is also the most common condition for the family Gesneriaceae in general. In our investigation of $H$. longisepala, in contrast, each of the cyme branches (including the single lateral flowers) was found to be subtended by a bract (Figs. 1e, h, 2b). We suppose that the subtending bracts of the branches of higher order were overlooked in previous studies of $H$. longisepala because the basal bracts are most evident and easily observed. In fact, in angiosperms in general, the branching nearly always occurs in an axil of a phyllome, and thus one (in case of monochasial branching) or two (in case of dichasial branching) bracts are normally observed at each node of a cymose inflorescence (Endress, 2010). Examples of an apparent lack of a subtending phyllome are usually the result of phyllome reduction, whereby the reduced bracts can frequently be observed at early stages of inflorescence development. The latter phenomenon is perhaps characteristic of most Gesneriaceae.

Notes on variation in flower morphology: Observations conducted by one of the authors (MSN) in Pu Hoat Nature Reserve revealed that $H$. longisepala shows variation with respect to the relative position of the stigmas and the fertile anthers. The difference is most probably due to differences in the pistil length, whereas the fertile stamens within the two morphologies are of the same structure. In the short-styled flower (Figs. 2d, i, 3b, d, e), the stigmas occupy a significantly more proximal position than the fertile anthers (behind them), being located approximately at the level of the vestigial anthers of the staminodes, while in the long-styled flower (Figs. 2e, h, 3a, c), the stigmas occupy a slightly more distal position than the fertile anthers (i.e., in front of them). A possible explanation for the different floral morphologies is that the flowers are strongly protandrous and that the flowers have simply been observed at different stages of anthesis. Indeed, significant ovary and style elongation during anthesis is known in genera of Gesneriaceae other than Henckelia, particularly in species of Aeschynanthus Jack (Middleton, 2007) and Oreocharis Benth. (Möller et al., 2018). Strong protandry is often associated with bird pollination in Gesneriaceae (Burtt \& Woods, 1975), although this would appear to be unlikely in Oreocharis and H. longisepala which otherwise have flowers typical for insect pollination. In our study, there did indeed appear to be some correlation between style length and the stage of anthesis of the flower as assessed by the appearance (freshness) of the corolla. However, in some cases, the short style morph was found in flowers with anthers which had dehisced some time before, which indicates that the possible pistil elongation takes place unusually long after the male stage of flowering is over (Fig. 3b). In Aeschynanthus, in contrast, the elongation of the style and ovary begins as soon as the stamens begin to wither and not after (pers. obs., DJM). The differences between Aeschynanthus and $H$. longisepala would suggest that the great lengthening of the styles is not necessarily employed for the same reasons or at least that the relative timing of each stage is markedly different.

Variation in pistil length among flowers of a given species is known in angiosperms that possess such kinds of stylar polymorphism as stigma-height dimorphism and heterostyly. Heterostyly implies a difference between the floral morphs in the position not only of the stigmas, but also of the anthers, i.e., stamen polymorphism as well as stylar polymorphism with opposite occurrence of short and long types of corresponding organs. Stylar polymorphism other than enantiostyly is quite rare in the family 
Gesneriaceae and has so far only been reported for one New World genus, Besleria L. (Podolsky, 1993; Barrett et al., 2000; Gao et al., 2006; Möller et al., 2019; Raju, 2019).

It is currently still unclear whether the polymorphism in H. longisepala is due to especially strong protandry or whether the species really possesses different floral morphs. A comprehensive study of the floral morphologies in H. longisepala is needed, including direct measurements of floral parts in a representative number of flowers and individuals, and observations on the dynamics of floral architecture from flower opening until withering. In particular, studies are lacking on the relative role of the various flower organs in pollination processes at the supposed different stages of anthesis. Finally, our results highlight the need for careful field studies and observations in other species of Gesneriaceae, particularly with regard to floral phenology and pollination.

\section{Acknowledgements}

We are indebted to Chun-Lei Xiang for his help with getting images of the specimens at KUN. We thank Eugene S. Popov for providing the map of Southeast Asia. We are grateful to the international cooperation mission with Russia, supported by the Vietnam Academy of Science and Technology (VAST) (Code Mission: QTRU01.09/19- 20), and funding support by Vietnam National Foundation for Science and Technology Development (NAFOSTED) under grant number 106.032017.300. The work of Maxim S. Nuraliev was supported by the Russian Foundation for Basic Research (project 19-54-54007) and conducted in accordance with Government order for the Lomonosov Moscow State University (project No. AAAA-A16-116021660105-3). We further like to thank the anonymous reviewers for constructive comments on the manuscript. The Royal Botanic Garden Edinburgh is supported by the Scottish Government's Rural and Environmental Science and Analytical Services Division. The work of David J. Middleton is supported by Singapore's National Parks Board.

\section{Literature Cited}

AVERYANOV L.V., LOC P.K., HIEP N.T. \& D.T. DOAN 2003a. Highland vegetation and flora of Van Ban District, Lao Cai province in northern Viet Nam. Turczaninowia 6: 47-86.

AVERYANOV L.V., LOC P.K., HIEP N.T. \& D.K. HARDER 2003b. Phytogeographic review of Vietnam and adjacent areas of Eastern Indochina. Komarovia 3: $1-83$.

BARRETT S.C., JESSON L.K. \& A.M. BAKER 2000. The evolution and function of stylar polymorphisms in flowering plants. Annals of Botany 85 (Supplement A): 1: 253-265. https://doi.org/10.1006/anbo.1999.1067

BORAH D., TARAM M., JOE A. \& S.V. NEELAMKAVIL 2019. Henckelia collegii-sancti-thomasii: a new species of Henckelia (Gesneriaceae) from Northeastern India. Phytotaxa 415(4): 247-251. https://doi.org/10.11646/ phytotaxa.415.4.10

BURTT B.L. \& P.J.B. WOODS 1975. Studies in the Gesneriaceae of the Old World XXXIX: towards a revision of Aeschynanthus. Notes from the Royal Botanic Garden Edinburgh 33: 471-489.

CAI L., LIU D.T., ZHANG P. \& Z.L. DAO 2019. Two new species of Henckelia (Gesneriaceae) from southeastern Yunnan, China. PhytoKeys 130: 151-160. https://doi.org/10.3897/phytokeys.130.33988

ENDRESS P.K. 2010. Disentangling confusions in inflorescence morphology: patterns and diversity of reproductive shoot ramification in angiosperms. Journal of Systematics and Evolution 48(4): 225-239. https:// doi.org/10.1111/j.1759-6831.2010.00087.x

FU L.F., MONRO A., DO T.V., NURALIEV M.S., AVERYANOV L.V., WEN F., XIN Z.B., MAISAK T.V., KUZNETSOV A.N., KUZNETSOVA S.P. NGUYEN K.S. \& Y.G. WEI 2019. Checklist to the Elatostema (Urticaceae) of Vietnam including 19 new records, ten new combinations, two new names and four new synonyms. PeerJ 7: e6188. https:/doi.org/ 10.7717/peerj.6188

GAO J.Y., REN P.Y., YANG Z.H. \& Q.J. LI 2006. The pollination ecology of Paraboea rufescens (Gesneriaceae): a buzz-pollinated tropical herb with mirror-image flowers. Annals of Botany 97(3): 371-376. https://doi.org/ 10.1093/aob/mcj044

HO P.H. 2000. An illustrated flora of Vietnam. Volume 3. Youth Publishing House, Ho Chi Minh City, Vietnam. p. 1020.

IUCN STANDARDS AND PETITIONS COMMITTEE 2019. Guidelines for Using the IUCN Red List Categories and Criteria. Version 14. Prepared by the Standards and Petitions Committee. Available at: http:/ 
/www.iucnredlist.org/documents/RedList Guidelines.pdf. (Accessed on 10.12.2019).

JANEESHA A.P. \& S. NAMPY 2020. A taxonomic revision of Henckelia (Gesneriaceae) in South India with one new species and seven lectotypifications. Rheedea this issue. https://dx.doi.org/10.22244/rheedea.2020.30.01.03

KANTHRAJ A.S., RANA T.S. \& K.N. NAIR 2020. Henckelia umbellata (Gesneriaceae), a new species from the Eastern Himalaya of India. Rheedea this issue. https://dx.doi.org/10.22244/rheedea.2020.30.01.08

KRISHNA G. \& P. LAKSHMINARASIMHAN 2018. A new species of Henckelia (Gesneriaceae) from Arunachal Pradesh, India. Taiwania 63(4): 397-401. https://doi.org/ 10.6165/tai.2018.63.397

LI H.W. 1983. Notulae de Gesneraceis Yunnanensibus. Bulletin of Botanical Research 3(2): 1-55.

LI H.W. 1991. Gesneriaceae. In: WU C.Y. (ed.), Flora Yunnanica. Volume 5. Science Press, Beijing. pp. 512688.

McNEILL J. 2014. Holotype specimens and type citations: General issues. Taxon 63(5): 1112-1113. https://doi.org/ $10.12705 / 635.7$

MIDDLETON D.J. 2007. A revision of Aeschynanthus (Gesneriaceae) in Thailand. Edinburgh Journal of Botany 64: 363-429. https://doi.org/10.1017/S096042860 7004878

MIDDLETON D.J., WEBER A., YAO T.L., SONTAG S. \& M. MÖLLER 2013. The current status of the species hitherto assigned to Henckelia (Gesneriaceae). Edinburgh Journal of Botany 70(3): 385-404. https://doi.org/ 10.1017/S0960428613000127

MÖLLER M., WEI Y.G., WEN F., CLARK J.L. \& A. WEBER 2016. You win some you lose some: updated generic delineations and classification of Gesneriaceae - implications for the family in China. Guihaia 36: 4460. https://doi.org/10.11931/guihaia.gxzw201512015

MÖLLER M., NAMPY S., JANEESHA A. P. \& A. WEBER 2017. The Gesneriaceae of India: consequences of updated generic concepts and new family classification. Rheedea 27(1): 23-41. https://dx.doi.org/10.22244/ rheedea.2017.27.1.5

MÖLLER M., ATKINS H.J., BRAMLEY G.L.C., MIDDLETON D.J., BAINES R., NGUYEN V.D., BUI H.Q. \& S. BARBER 2018. Two new species of Oreocharis (Gesneriaceae) from northern Vietnam. Edinburgh Journal of Botany 75(3): 309-319. https:// doi.org/10.1017/S0960428618000148

MÖLLER M., ATKINS H., BARBER S. \& D. PURVIS 2019. The living collection at the Royal Botanic Garden Edinburgh illustrates the floral diversity in Streptocarpus
(Gesneriaceae). Sibbaldia 17: 155-177. https://oi.org/ 10.23823/Sibbaldia/2019.272

NEWMAN M., KETPHANH S., SVENGSUKSA B., THOMAS P., SENGDALA K., LAMXAY V. \& K. ARMSTRONG 2007. A checklist of the vascular plants of Lao PDR. Royal Botanic Garden Edinburgh, Edinburgh. p. 394.

PELLEGRIN F. 1926. Les Gesnéracées-Cyrtandrées d'IndoChine. Bulletin de la Société Botanique de France 73(3): 412-429. https://doi.org/10.1080/00378941.1926.10833599

PELLEGRIN F. 1930. Gesnéracées (Cyrtandrées). In: LECOMTE H. (ed.), Flore générale de l'Indo-Chine. Volume 4(5). Masson et Cie, Paris. pp. 487-565.

PHUONG V.X. 2005. Gesneriaceae. In: BAN N.T. (ed.), Checklist of plant species of Vietnam. Volume 3. Agriculture Publishing House, Hanoi. pp. 238-240.

PHUONG V.X. 2017. Gesneriaceae. In: KHOI N.K. (ed.), Flora of Vietnam. Volume 18. Publishing House for Science \& Technology, Hanoi. p. 416.

PODOLSKY R.D. 1993. Evolution of a flower dimorphism: how effective is pollen dispersal by "male" flowers? Ecology 74(8): 2255-2260. https://doi.org/10.2307/ 1939578

RAJU A.J.S. 2019. Stylar polymorphisms in flowering plants: an overview. In: BAHADUR B., KRISHNAMURTHY K.V., GHOSE M. \& S.J. ADAMS (eds.), Asymmetry in Plants: Biology of Handedness. CRC Press, Boca Raton. pp. 301-317.

SIRIMONGKOL S., PARNELL J.A.N., HODKINSON T.R., MIDDLETON D.J. \& C. PUGLISI 2019. Five new species of Henckelia (Gesneriaceae) from Myanmar and Thailand. Thai Forest Bulletin (Botany) 47(1): 3854. https://doi.org/10.20531/tfb.2019.47.1.08

TAKHTAJAN A. 1986. Floristic regions of the world. University of California Press, Berkeley. p. 522.

TURLAND N.J., WIERSEMA J.H., BARRIE F.R., GREUTER W., HAWKSWORTH D.L., HERENDEEN P.S., KNAPP S., KUSBER W.H., LI D.Z., MARHOLD K., MAY T.W., MCNEILL J., MONRO A.M., PRADO J., PRICE M.J. \& G.F. SMITH (eds.) 2018. International Code of Nomenclature for Algae, Fungi, and Plants (Shenzhen Code) adopted by the Nineteenth International Botanical Congress Shenzhen, China, July 2017. Regnum Vegetabile 159. Koeltz Botanical Books, Glashütten. p. 254. https://doi.org/ 10.12705/Code.2018

WANG W.T. 1984. A new genus of Gesneriaceae from Yunnan. Acta Botanica Yunnanica 6(4): 397-401.

WANG W.T. 1985. A revision of the genus Chirita in China (I). Bulletin of Botanical Research. Harbin 5(2): 71-97. 
WANG W.T., PAN K.Y. \& Z.Y. LI 1990. Gesneriaceae. In: WANG W.T. (ed.), Flora Reipublicae Popularis Sinicae. Volume 69. Science Press, Beijing. pp. 125-581.

WANG W.T., PAN K.Y., LI Z.Y., WEITZMAN A.L. \& L.E. SKOG 1998. Gesneriaceae. In: WU Z.Y. \& P.H. RAVEN (eds.), Flora of China. Volume 18. Science Press, Beijing and Missouri Botanical Garden, St. Louis. pp. 244-401.

WANG Y.Z., MAO R.B., LIU Y., LI J.M., DONG Y., LI Z.Y. \& J.F. SMITH 2011. Phylogenetic reconstruction of Chirita and allies (Gesneriaceae) with taxonomic treatments. Journal of Systematics and Evolution 49(1): 50-64. https://doi.org/10.1111/j.1759-6831.2010.00113.x

WEBER A., MIDDLETON D.J., FORREST A., KIEW R., LIM C.L., RAFIDAH A.R., SONTAG S., TRIBOUN P., WEI Y.G., YAO T.L. \& M. MÖLLER 2011. Molecular systematics and remodelling of Chirita and associated genera (Gesneriaceae). Taxon 60(3): 767790. https://doi.org/10.1002/tax.603012

WEI Y.G., WEN F., MÖLLER M., MONRO A., ZHANG Q., GAO Q., MOU H.F., ZHONG S.H. \& C. CUI 2010. Gesneriaceae of South China. Guangxi Science and Technology Publishing House, Guilin. p. 777.

XU W.B., GUO J., PAN B., ZHANG Q. \& Y. LIU 2017. Diversity and distribution of Gesneriaceae in China. Guihaia 37(10): 1219-1226. https://doi.org/10.11931/ guihaia.gxzw201707004

YANG B., DING H.B., FU K.C., YUAN Y.K., YANG H.Y., LI J.W., ZHANG L.X. \& Y.H. TAN 2019. Four new species of Gesneriaceae from Yunnan, Southwest China. PhytoKeys 130: 183-203. https://doi.org/10.3897/ phytokeys.130.34001

YANG W.Z. \& Y.M. YANG 2014. Conservation priorities of wild plant species with extremely small populations (PSESP) in Yunnan Province. Journal of West China Forestry Science 43(4): 1-9. 